\title{
The place of local government bodies in a unified system of public government bodies of Russia: issues of theoretical implementation
}

\author{
Levan T. Chikhladze ${ }^{1} \mathbb{D}$, Olga Yu. Ganina ${ }^{2}$ \\ ${ }^{1}$ Peoples' Friendship University of Russia (RUDN University), Moscow, Russian Federation \\ ${ }^{2}$ Orenburg Institute (branch), Moscow State University named after O.E. Kutafina \\ (Moscow State Law Academy), Orenburg, Russian Federation \\ \ogau2007@mail.ru
}

\begin{abstract}
The introduction of amendments to the Constitution of the Russian Federation necessitated a theoretical understanding of the established legal norms after their legislative update. Inclusion in the text of the state basic law of the «public authorities» concept, which requires its theoretical understanding, is of unconditional interest. To identify the specifics of the position of local selfgovernment bodies in the state mechanism, depending on a particular model of state governance, it is necessary to study the experience of organization and functioning of the state apparatus at various historical stages. The aim of the study is to analyze the concepts of theoretical scientists on the legal nature and role of public authorities in the life of the state and to determine the position of local authorities in the public authority system in connection with consolidation of their unity with public authorities in the basic law of the state. In the process of research, the authors used general scientific methods of analysis and synthesis, as well as specific scientific methods - historical and comparative legal. It is concluded that, despite the novelty of the concept of «public authorities» in the text of the basic law of the state, conceptually it does not change the basis of the functional interaction of public authorities and local governments. Nevertheless, the normative consolidation of the unity of public authorities in the Constitution of the Russian Federation does not abolish the organizational separation of local selfgovernment and its bodies from public authorities.
\end{abstract}

Key words: public authority, bodies of public authority, local government, bodies of local government

Conflict of interest. The authors declare no conflict of interest.

The participation of the authors: Chikhladze L.T. - the concept of the study, analysis of the data obtained, writing the text; Ganina $O . Y u$. - research concept, collection and processing materials, text writing.

Article received 14st April 2021

Article accepted 15th October 2021

(C) Chikhladze L.T., Ganina O.Yu., 2021

This work is licensed under a Creative Commons Attribution 4.0 International License

https://creativecommons.org/licenses/by/4.0 


\title{
For citation:
}

Chikhladze, L.T., Ganina, O.Yu. (2021) The place of local government bodies in a unified system of public government bodies of Russia: issues of theoretical implementation. RUDN Journal of Law. 25 (4), 750 - 767. DOI: 10.22363/2313-2337-2021-25-4-750-767

DOI: $10.22363 / 2313-2337-2021-25-4-750-767$

Научная статья

\section{Органы местного самоуправления в единой системе публичной власти России: вопросы теории и истории}

\author{
Л.Т. Чихладзе ${ }^{1}$, О.Ю. Ганина ${ }^{2} \bowtie$ \\ ${ }^{1}$ Российский университет дружбы народов, г. Москва, Российская Федерация \\ ${ }^{2}$ Оренбургский институт (филиал), Московский государственный университет \\ имени О.Е. Кутафина (МГЮА), г. Оренбург, Российская Федеращия \\ $\triangle$ ogau2007@mail.ru
}

\begin{abstract}
Аннотация. Внесение поправок в Конституцию Российской Федерации обусловило потребность теоретического осмысления действующих правовых норм после их законодательного обновления. Безусловный интерес вызывает включение в текст основного закона государства понятия «органы публичной власти». Необходимо изучить опыт организации и функционирования государственного аппарата на различных исторических этапах, чтобы выявить специфику положения органов местного самоуправления в государственном механизме в зависимости от той или иной модели управления государством. Целью исследования является анализ концепций ученых-теоретиков о юридической природе и роли органов публичной власти в жизни государства и определение положения органов местного самоуправления в системе публичной власти. Использовались общенаучные методы анализа и синтеза, а также частнонаучные методы — исторический и сравнительно-правовой. Сделан вывод о том, что, несмотря на закрепление понятия «органы публичной власти» в тексте основного закона государства, концептуально оно не меняет основу функционального взаимодействия органов государственной власти и органов местного самоуправления. Тем не менее, нормативное закрепление единства органов публичной власти в Конституции Российской Федерации не отменяет организационное обособление местного самоуправления и его органов от органов государственной власти.
\end{abstract}

Ключевые слова: публичная власть, органы публичной власти, местное самоуправление, органы местного самоуправления

Конфликт интересов. Авторы заявляют об отсутствии конфликта интересов.

Информация о вкладе авторов: Чихладзе Л.Т. — концепция исследования, анализ полученных данных, написание текста; Ганина О.Ю. - концепция исследования, сбор и обработка материалов, написание текста.

Дата поступления в редакцию: 14 апреля 2021 г. Дата принятия к печати: 15 октября 20212. 


\section{Для цитирования:}

Чихладзе Л.Т., Ганина О.Ю. Органы местного самоуправления в единой системе публичной власти России: вопросы теории и истории // RUDN Journal of Law. 2021. Т. 25. № 4. C. 750 -767. DOI: 10.22363/2313-2337-2021-25-4-750-767

\section{Introduction}

The effective functioning of the state directly depends on the well-coordinated work of public authorities. It is they who develop programs to provide citizens and civil society institutions with everything they need within the established legal space and interact with each other in order to achieve the most optimal results of the tasks set.

Modern realities confirm the development of new standards for governing the Russian state after the legislative update in 2020 of the procedure for the formation and powers of a number of government bodies. One of the key novelties was the inclusion of the concept of «public authorities» in the text of the Constitution of the Russian Federation. This step has raised questions about how the updated system of government bodies will function in the state and what will change in the interaction between government bodies at different levels after the amendments inclusion into the text of the basic law of the state.

Even before its inclusion in the text of the Constitution of the Russian Federation, the concept of «public authorities» aroused increased interest among researchers and led to the emergence of various conceptual provisions. With consolidation of the «public authorities» concept in the text of Chapter 8 of the Constitution of the Russian Federation, the discussion of its legalization in the basic law reached a new level. Of course, the position of the lower level of government - local self-government bodies, which from now on were included de jure in the system of public authorities - was not left without attention either. In this regard, it is necessary to study the concepts of theoretical scientists on the legal nature and role of public authorities in the life of the state and society and to determine the position of local governments in the public power system, which forms the purpose of this study. The solution to this goal is achieved by performing the following tasks:

1) to study the positions of theoretical scientists on the legal nature of public authority and its bodies,

2) to analyze the evolution of public authorities and local self-government bodies in order to disclose their place in the system of public authority,

3) to study the place of local self-government bodies in the system of public authorities in the context of the adopted constitutional novelties.

The methodological basis of the research was formed by general scientific research methods, which allowed to analyze the legal nature of the phenomenon of «public authorities» and its interpretation by domestic and foreign theoretical scientists. Along with general scientific methods, special scientific research methods (historical, comparative legal, etc.) were used; they contributed to identifying trends in the development of the state apparatus in the Russian Federation and determining the specifics of interaction between state authorities and local governments in particular historical periods. 


\section{Evolution of understanding of the legal nature of public government and its bodies by domestic theoretical scientists}

The legal nature of public authority and the bodies implementing it has repeatedly become the subject of research by domestic and foreign scientists. Nevertheless, a unified concept about what public power is has not yet been developed. According to S.A. Avakyan, public power is a broad phenomenon that incorporates the fullness of people's power and is implemented in the form of state power and local self-government (Avakyan, 2018). From the point of view of I.K. Sovetov, the public authorities are characterized by formal separation from society and not coincidence with the population of the country; its public character is regarded as «public», being «at the disposal of the society» (Sovetov, 2020:45). The author in his position is close to the point of view of V.E. Chirkin, arguing that public power should be understood as a variant of social power, recognized as public, since it is the result of implementation of objective needs in society; it is isolated from the people and, in the constitutional and legal order, is endowed by the people with the right to exercise powers on their behalf (Sovetov, 2020:45). V.E. Chirkin asserts that public power should be associated with social power, viewed as its kind; at the same time, organization of this type of power is possible in public entities strictly on specific lands, due to which this power is of a public nature (Chirkin, 2008). In the opinion of I.K. Sovetov and N.L. Maltsev, the social nature is manifested in the function of public authority, which reflects the external side of its activities, i.e., the sphere of influence on the social environment in order to achieve certain goals with a focus on the powers granted (Maltsev, 2009; Sovetov, 2020). N.A. Vlasenko notes, that the public power is one of the main features of the state, meaning that there is no merger of the state with society and realization through special bodies state and municipal - whose task is to manage and organize society, develop and apply legal acts binding on population, as well as ensure law and order (Vlasenko, 2011).

The ambiguity of the nature of public power raises the issue of relationship between the concepts of «state power», «social power» and «public power». Soviet legal science distinguished two directions regarding the connection between public and social power. The first approach asserted their equality. Thus, according to L.A. Grigoryan, the term «public power» should be understood as social power operating in any society (Grigoryan, 1965:17). The second approach denied the equivalence of public and social authorities since the first is synonymous with state and political power. A similar point of view can be found, for example, in the works of A. I. Kim (Kim, 1975:65).

As for correlation of «public power» and «state power» concepts, there was a tendency to treat them as identical over a long period of time. For example, M.I. Baytin understood political power as the power emanating from the state or exercised with its direct or indirect participation (Baytin, 2005:83). A similar trend is noted by N.V. Malyavkina in her analysis of the positions of Russian theoretical scientists on the relationship between «state power» and «public power» concepts (Malyavkina, 2011). 
Modern legal science denies the equivalence of these concepts. According to S.A. Komarov, the concept of «state power» has a narrower meaning since it includes only one element of the political structure of society — the state (Komarov, 2005:145). Vasiliev, A.V. Elkina, A.E. Irtegova and A.E. Yagovtsev also claim that there is no identity between the concepts of public and state power (Elkina, Irtegova \& Yagovtsev, 2020; Vasiliev, 2019). A.N. Chertkov, believes that public power is a special power that does not coincide in volume with the power of the state (Chertkov, 2021:50). According to A.A. Kashkarov, public and state authorities are not identical, since in a democratic state where developed institutions of civil society operate, a number of functions of state power are performed by local self-government bodies, although the exercise of their powers is ensured by the force of state coercion and authority of state powers, which can be confirmed by legal norms of Russian legislation (Kashkarov, 2015:173). Basically, the general trend of recent research in this area is to differentiate the concepts of «public power» and «state power», since public power is characterized by diverse organizational forms that are not limited to state power. To prove this thesis, E.P. Tarasova cites the provision of the Russian Constitution on the division of public power into state power and local self-government as independent elements of this power (Tarasova, 2010:167).

Analyzing the concepts of public and state power, the authors thought not only about the boundaries and components of public power, but also about those bodies that can be attributed to exercising such power in the state. For example, D.G. Thalberg talked about the possibility of attributing the judicial power of monasteries to the power of public authorities. He wrote: «If it is impossible in such a phenomenon to see identification of the judicial power of monasteries with any private law, then granting the right in all private matters to the owner by court, who is in this case the clergy, indicates that judicial functions still did not have time to acquire the character and significance of a public authority» (Talberg, 1880:47-48). Nevertheless, according to D.G. Talberg, with strengthening the position of the Moscow state and further centralization and annexation of new lands to Moscow, the court as a social and public institution acquires different positions; at the same time, "some offences that were not subject to possessory court according to the general rule were singled out" (Talberg, 1880:47-48).

Researchers are also interested in the issue of the role of public authorities in the state. In the scientific literature of the pre-revolutionary period, there is a tendency to analyze the role of these bodies from the standpoint of democratic principles development. Distinguishing democracy into a democracy regulated by laws and «extreme» democracy, M.M. Kovalevsky, noted that the first version of democracy is characterized by equality of people as citizens among themselves, while «extreme» democracy establishes equality not only of people, but also of public authorities (Kovalevsky 1899, I:353). Thus, the author spoke about the equal position and interests of society in the person of its citizens and the state. Another pre-revolutionary researcher K.D. Kavelin argued that the authorities, being a mechanism that clearly shows the legal idea of the state, are a legal principle themselves, the principle that is 
implemented in the form of government institutions and positions occupied by people; they exhibit both a state and civil character. The state features manifest themselves through the institutions of public authority, the civil features - through "private persons" (Kavelin, 1904:773-774).

Unlike pre-revolutionary researchers, Soviet authors put forward their positions in the spirit of dogmatism formed after the Bolsheviks came to power; they stemmed from prevalence of state-collective principles. For example, L.G. Raisky directly linked functioning of public authorities in the pre-revolutionary period with domination of state administration by the capitalist elite, who, in order to maintain supremacy over their fellow citizens, kept all public authorities at their service (Raisky, 1930: 228). The Soviet authorities were characterized by collective principles, strict hierarchy and subordination of lower bodies to higher ones, even in cases of individual representatives of power. For example, analyzing Art. 91 of the 1922 Criminal Code of the RSFSR, E.Ya. Nemirovsky suggested that a representative of power be understood as any person to whom the state grants this power, including a lower body; they are all public authorities (Nemirovsky, 1924:237). According to the author's conclusion, Art. 91 contains provisions directly affecting the appropriation of public authority; first of all, it concerns functions' performance of an official as a state body (Nemirovsky, 1924:239).

The analysis of "public power" concept by theoretical scientists was inextricably linked with attempts to formulate the definition of the "public body" concept. As with the concept of "public power", there is no consistency in understanding the "public body" concept. Currently, the following conceptually different definitions can be distinguished. According to E.V. Suslin and D.V. Rybin, a public body should be understood as a relatively independent, separate link of the state apparatus, which is organized by the state for implementing a specific type of state activity, endowed with the appropriate competence and relies on the material, organizational and coercive power of the state in the process of exercising its powers (Suslin \& Rybin, 2018:133). From the point of view of A.A. Klishas, three approaches can be distinguished in understanding of the "public body" concept. It is an integral part of the state mechanism, which is endowed with state-power authorities and participates in the implementation of the functions of the state; it is a political institution organized with the aim of performing the functions of the state and endowed with authorities of a public-power character to perform them; it is an organization or sole official with powers of authority, which is manifested through issuing of binding decisions, and supervising their implementation (Klishas, 2019:133). Unlike previous authors I.L. Chestnov believes that a public authority is an organized collective of people created in accordance with the procedure established by law and endowed with powers of authority; they are called upon to solve the tasks established by law and perform the functions of the state in a certain sphere of society (Chestnov, 2019:44). Thus, the range of definitions of the 'public body' concept is very diverse and is supplemented by new qualitative characteristics, based on the emerging trends in the development of state apparatus. At the same time, it should be noted that until now clear definitions of the concepts 
of «public power» and «public body» have not been formed due to the variety of approaches and conceptual vision of the authorities' position at different levels in the system of public power.

\section{State authorities and local government bodies as a link of the public government system in Russia}

Over a long period of the Russian state existence, the state apparatus has been constantly improving and changing. Gradually, the two-tier system of state administration was replaced by a three-tier hierarchy, which currently forms the basis of the government of the Russian Federation. A special place in this system is occupied by local self-government bodies, the formation and development of which went in parallel with the development of state bodies. It was the specifics of the interaction of public authorities of different levels with each other that previously determined and establishes in modern realities one or another model of public administration. In this regard, the study of public and local authorities' evolution in Russia allows us to highlight not only the mechanisms of formation and functioning of the system of public authorities in specific historical periods, but also to identify the features of their interaction and interdependence.

In fact, public power emerged a long time ago. In Russian history, one can trace it from the formation of the Old Russian state in the middle and the second half of the 10th century, when the newly formed state was headed by the Rurik dynasty; they formed their own apparatus of princely administrative and judicial administration, territorial division into volosts with cities and graveyards, and fixed tax system (Degtyareva \& Poltorak (ed.), 2005:46). The state became a political organization of the people, took shape together with the people and experienced influence of all the elements and conditions that united the people into a single whole (Belyavsky, 1094:6).

At the first stage of Ancient Rus formation, a model of combining the city-state with the princely system of government flourished in state administration (Yeremyan $\&$ Fedorov, 1998). However, later, the gradual increase of the Grand Duke's influence and weakening of people's assembly positions, which over time began to solve mainly private economic problems became a distinctive feature of the power hierarchy of the Old Russian state (Khimich, 2019:37). At the same time, in Novgorod and Pskov republics, the princely power did not play such a serious role as in other Russian lands. The role of the Novgorod prince was eventually reduced to the functions of a mediator and magistrate engaged for these purposes by the city (Yeremyan \& Fedorov, 1998). The state principle in such scheme was represented by the princely administrative and managerial apparatus, while local self-government was primarily represented by the veche, both citywide and in individual territories, which consisted of the male population and had rather extensive powers. It was the citywide veche that elected a mayor, a village elder (tysyatsky) and other local bodies. In fact, such systems survived during the period of feudal fragmentation and beginning of the Russian lands centralization. 
The unification completion of the Russian lands around Moscow led to the reform of the state government bodies system. Ivan IV actively contributed to the development of ideas of local self-government, formalizing them in a legislative form. The basis of local self-government during that period was made up of volostels and governors appointed by the prince. Later, they were replaced by elected zemstvo and guba elders (Khimich, 2019:37).

Since the end of the XVI century local power was concentrated in the hands of the governors appointed by the central power. It was the voivods, as representatives of Moscow, who ruled the lands entrusted to them and exerted a serious influence on the formation of local self-government bodies.

The next stage in the formation of Russian government bodies system was the Peter the Great reforms. Under him, a clear division of public authorities into three levels took place: central authorities formed government bodies headed by the monarch, regional authority was represented by governor's power, and local level authority took shape of the lower government bodies. As a result of the reform of urban self-government, a new body called the Town Hall appeared in Russia; it was the body of city self-government, which constituted a state institution in charge of managing urban population.

The government of Catherine II made further attempts to transform local government. In 1775, the "Institution for the Governance of Provinces", which consolidated the foundations for reforming local government, was issued (Khimich, 2019:39). The new division of the country into provinces and counties formed the general principles of interaction between regional and local authorities; while the governor-general controlled the work of local government bodies, direct local government was concentrated in the hands of the nobility assemblies, which elected the local administration and the court. Nevertheless, strengthening of the absolute monarchy inevitably brought the central authorities to the fore, which, through the regional government apparatus, controlled the local government.

By the 19th century, various concepts had been formed concerning what local self-government in the state should be like. Some foreign and domestic thinkers stated the need to preserve the independent economy of the community, free from state control. However, in the Russian Empire, the independence of local self-government, despite the restoration by Alexander I of the Letters patent to the cities of 1785 after its abolition by Paul I, was minimal.

The first half of the 19th century passed under the auspices of strengthening regional power, which in practice was only formally controlled from the center. The powers of the governor as the head of local administrations during that period increased sharply, while the role of the noble assemblies in local government, despite the importance of that political institution, was reduced to a minimum. Local selfgovernment bodies found themselves under the strict control of the regional authorities. Such tendency in public administration raised interest of theoretical scientists to that issue. Researchers attempted to substantiate or propose a different option for forming and interacting of public authorities. 
By the middle of the XIX century the idea of the need to transfer to the communities a number of new powers that directly affected their interests, including the local police, began to be expressed more and more often. For example, N.N. Belyavsky supported the thesis of self-government as part of a unified state administration, which could decide independently the issues of local importance. However, the author admitted that the issue of combining such "co-management" in the person of both the state and the community was rather complicated and had not been resolved by that time (Belyavsky, 1904:8). Arguing about the specifics of public administration in that period, N.N. Belyavsky cited as an example the position of L. von Stein. According to him, there is only a single state administration, while the communities through their bodies realize goals common to government officials; however, local governments have more independence from the government than civil servants. Therefore, the fundamental idea of the scholar was the thesis of selfgovernment as a community body that pursues national interests. According to N.N. Belyavsky, the concept of self-government at that time absorbed both a legal basis, related to the issue of independent management of the community by its special interests, and a political one, when community officials acted as part of public administration, which recognized the difference between the "public administration" and "self-government" concepts only as the method of management (Belyavsky, 1904:9).

After abolition of serfdom in 1861, the issue of reforming the system of local self-government became urgent. Nevertheless, all the proposed novels in one way or another were associated with the central government attempts to preserve the nobility dominance in the government. In volosts, management was in the hands of the volost gathering, volost foreman, volost government and volost peasant court, in the villages it realized in the village gathering and village headman (Chepurnova \& Filippova, 2011). Control over the self-government of peasants was in the hands of conciliators, county congresses and provincial peasant presences, where the nobility predominated, which hindered the development of volost and rural self-government. Besides, the estate principle continued to operate in local self-government, which made peasant communities dependent on local institutions formed from landowners. However, after 1864 the noble self-government was deprived of the right to manage the affairs of the local economy of provinces and counties. The updated local administration system included zemstvo electoral congresses, zemstvo assemblies and zemstvo councils. The formed bodies, however, did not receive full independence since their decisions had to be approved by the governor or the minister of internal affairs. In contrast to rural selfgovernment, the city government bodies, under the 1870 reform, received relatively wide independence in solving urban issues, although some of their decisions also required the approval of the provincial administration or the ministry of internal affairs. Nevertheless, local councils resolved many issues on their own.

During the reign of Alexander III, the class principle in local self-government bodies was strengthened. The principle of election of the chairman and members of the council was replaced by the principle of approval, and the right to appeal against nonapproval was withdrawn from the zemstvo assemblies. The governor had the power to 
terminate the decisions of the zemstvo assemblies at his own discretion. Selfgovernment in the countryside was under the control of zemstvo district chiefs. All those testified to strengthening the positions of the central and regional authorities, while the position of local self-government bodies remained rather vague. At the beginning of the XX century N.N. Belyavsky wrote, that the state had a crown administration and self-government bodies, and the latter were not fully developed conceptually. The researcher put the question of "What is self-government, what are its functions and tasks?" and failed to find the answer since the exact legal structure of self-government before the beginning of the XX century was not formed because in each state self-government had its own specifics. As noted by N.N. Belyavsky, selfgovernment could not at that time be justified by an exact legal definition (or term), but it could be called a constantly changing reflection of the political trends of the moment (Belyavsky, 1904: 8).

With Bolsheviks coming to power, local self-government underwent major changes. The previous model was basically eliminated, while the new one developed in the mainstream of public administration. G.S. Gurvich argues, that if the public theory of self-government was characterized by an orientation towards isolation of society from the state, and the state saw in local self-government a way of selforganization of the ruling class (Gurvich, 1924: 40), then with the approval of the state theory of self-government, local self-government bodies were considered as state institutions and part of administrative hierarchy. According to him, one can speak of self-government bodies as local government bodies and state bodies in this period (Gurvich, 1924:41).

Generally speaking, the system of government that took shape with Bolsheviks determined the prospects for self-organization and self-government at the local level throughout the entire period of government in Soviet times.

\section{Local government bodies in the system of public government from the position of the 2020 Constitutional reform}

The issue of public administration model again appeared on the agenda after the collapse of the USSR and formation of a sovereign state of the RSFSR, later the Russian Federation. The Constitution of the Russian Federation, adopted by the nation-wide vote on December 12, 1993, formed a new system of public authorities in comparison with Soviet times. A fundamental difference from the previous period was separation of local self-government as an independent political institution that was not part of the system of state power (Byalkina, 2006). Nevertheless, both state authorities and local self-government bodies have formed, in their totality, a single system of public power, acting in the interests and on behalf of the people as the bearer of sovereignty and the only source of power in the Russian Federation (Maliavkina, 2011).

The concepts of "public power", "public body" were legalized in the text of the Constitution of the Russian Federation only in 2020 and became the logical result of the established model of public administration. However, the practice of applying these concepts in the texts of legal documents had already developed by this time, as 
evidenced by the analysis of the decisions of the Constitutional Court of the Russian Federation (Shugrina, 2016:166-167). In its Resolution of January 24, 1997, the high court recognized the name of a type of public power for local self-government and its bodies $^{1}$. The following year, a decision followed in which the term "levels of public power" was used ${ }^{2}$. By the decision of the Constitutional Court of the Russian Federation of April 2, 2002 revealing the nature of the local level of power, local selfgovernment was considered as public (municipal) power ${ }^{3}$. These decisions testify to a consistent line of the high court in relation to the unity of the public power system, which was formed in consideration of different cases (Shugrina, 2016:167).

Logical development of the position of the Russian Constitutional Court in interpreting public power and its bodies realized in the Conclusion of March 16, 2020, adopted within the ongoing constitutional reform. The high court noted the derivation of the category "unified system of public power" from the "statehood" and "state" concepts, understood as a political union of the multinational Russian people, whose power operates in the state as a single systemic unity in specific organizational forms established by the basic law. Proceeding from this, the Constitutional Court concluded that local self-government bodies, without being part of the system of state power bodies, are part of a single system of public power of the political union of a multinational people ${ }^{4}$. Integration of local self-government in the person of its bodies into the general system of government in a specific territory and considering interaction with public authorities was emphasized.

The description of the "unified system of public power" concept can be found in the norms of Part 1 of Art. 2 of the Federal Law "On the State Council of the Russian Federation". According to this document, the system of public power includes federal bodies of state power, bodies of state power of the constituent entities of the Russian

\footnotetext{
${ }^{1}$ Resolution of the Constitutional Court of the Russian Federation No. 1-P of January 24, 1997 "In the case of checking the constitutionality of the Law of the Udmurt Republic" of April 17, 1996; "On the system of public authorities in the Udmurt Republic or in the case of checking the constitutionality of the Law of the Udmurt Republic" of April 17 1996: "On the system of public authorities in the Udmurt Republic". Collected Legislation Russian Federation. 1997. No. 5. Art. 708.

${ }^{2}$ Resolution of the Constitutional Court of the Russian Federation No. 17-P of June 10, 1998 "In the case of checking the constitutionality of the provisions of paragraph 6 of Article 4, subparagraph" and "of paragraph 3 and paragraph 4 of Article 13, paragraph 3 of Article 19 and paragraph 2 of Article 58 of the Federal Law" of September 19, 1997; "On the basic guarantees of electoral rights and the right to participate in a referendum of citizens of the Russian Federation". Collected Legislation Russian Federation. 1998. No. 25. Art. 3002.

${ }^{3}$ Resolution of the Constitutional Court of the Russian Federation No. 7-P of April 2, 2002 "In the case of checking the constitutionality of certain provisions of the Law of the Krasnoyarsk Territory" On the procedure for recalling a deputy of a representative body of local self-government "and the Law of the Koryak Autonomous Okrug" On the procedure for recalling a deputy of a representative body of local self-government, an elected official of local self-government in the Koryak Autonomous Okrug "in connection with the complaints of the applicants A.G. Zlobin and Yu.A. Khnaeva“. Collected Legislation Russian Federation. 2002. No. 14. Art. 1374.

${ }^{4}$ Conclusion of the Constitutional Court of the Russian Federation dated March 16, 2020 No. 1-3 "On the compliance with the provisions of Chapters 1, 2 and 9 of the Constitution of the Russian Federation of the provisions of the Law of the Russian Federation on the amendment to the Constitution of the Russian Federation" On improving the regulation of certain issues of organization and functioning of public authorities, "as well as on the compliance with the Constitution of the Russian Federation of the procedure for the entry into force of Article 1 of this Law in connection with the request of the President of the Russian Federation." Available at: http://www.ksrf.ru/ [Accessed 30th March 2021].
} 
Federation, other state bodies, and local self-government bodies in their totality. On the principles of coordinated functioning, they are established in accordance with the basic law of the state and the rules of organizational, legal, functional, financial and budgetary interaction, including the transfer of powers between levels of public power, and realize their activities in order to observe and protect the rights and freedoms of man and citizen and create conditions for socio-economic development of the state ${ }^{5}$.

Consolidation of the constitutional and legal status of the State Council of the Russian Federation in the text of the Constitution of the Russian Federation has farreaching consequences. According to paragraph «e.5» of Art. 83 of the basic law and Part 1 of Art. 3 of the above-mentioned Federal Law, the purpose of the State Council of the Russian Federation is to ensure the coordinated functioning and interaction of public authorities, to determine the main directions of the domestic and foreign policy of Russia and the priority directions of the socio-economic development of the state. This body, as an integral part of a unified system of public power, is called upon to coordinate the actions of federal, regional and local authorities, which will allow the development of unified standards of state policy, implemented through a unified system of public power. On the one hand, the vertical structure of relations between different levels of power is being built up by legislation; on the other hand, conditions are being created for coordinating positions and exchanging experience between different territories of the state to strengthen the vertical of power. Thus, the State Council of the Russian Federation performs the function of a structural unit of the public power system, ensuring control by the federal center; at the same time, its activities are designed to maintain effective feedback with regional and local authorities. The inclusion of local self-government bodies in the unified system of public authorities inevitably puts their activities in the focus of the State Council's supervision, which, due to its coordinating function, will contribute to strengthening interaction between public authorities and local self-government bodies, established by Part 3 of Art. 132 of the Russian Constitution.

The categories "public power", "system of public power", "public bodies" are mentioned in the updated articles of the Constitution of the Russian Federation: Part 1 of Art. 67, item "g" of Art. 71, part 1 of Art. 80, item "e.5" Art. 83, part 3 of Art. 131. At the same time, the basic law of the state does not disclose the definition of these concepts. The novelty of these concepts in the text of the Russian Constitution, at the same time, does not mean that they conceptually change the basis of the functional interaction of public authorities at various levels. This is manifested, for example, in the norm of Part 2 of Art. 132 of the Constitution, according to which local selfgovernment bodies can be endowed with federal law, the law of a constituent entity of the Russian Federation with separate state powers in the event of transfer of material and financial resources necessary for implementation of these powers. In this case, the state is vested with the authority to control the implementation of the delegated powers ${ }^{5}$.

\footnotetext{
${ }^{5}$ Constitution of the Russian Federation. Adopted by popular vote on December 12, 1993 (with changes approved during the all-Russian vote on July 1, 2020). Rossiyskaya Gazeta. 1993 December 25 (No. 237); Russian newspaper. 2020.4 July (No. 144).
} 
Despite the declared unity of public authorities, the main purpose of which is to solve state problems at different levels based on interaction and coordination, the basic law of Russia emphasizes the organizational separation of local government and its bodies from state power and its bodies. This principle is laid down in Art. 12 of the Constitution of the Russian Federation ${ }^{6}$, which emphasizes that local government bodies are not part of the system of government bodies. This provision constitutes the legal basis for interaction between authorities at different levels. At the same time, the de jure inclusion of local self-government bodies in the unified system of public authorities brings interaction between them and public authorities to a new level. The fact is that the lower level of power is as close as possible to the population that independently decides on formation of certain local self-government bodies.

Currently, due to the inclusion of the novels concerning formation of the structure of local self-government bodies in Part 1 of Art. 131 of the Constitution, the diversity of local self-government bodies should be determined by the federal legislator ${ }^{7}$. Despite the fact that this situation is not new in the normative consolidation of functioning of government bodies, nevertheless, the legalization of this provision in the Constitution emphasizes the special role of the federal legislator in this matter. Thus, a logical chain of establishing general principles for the formation of public authorities of different levels is enshrined in the basic law of Russia, according to which local governments are considered as part of a multi-level system of public power with clearly distributed functions and powers and are an integral element of a single state mechanism. Due to these circumstances, local self-government can be effective only when it is in harmonious relationship with public authorities (Chikhladze, Laricheva \& Khazova (eds.), 2020:331).

In this regard, the problem of delimiting the spheres of state power and local selfgovernment as forms of exercising public power acquires special significance. As noted by N.V. Antsiferov, provisions of Part 1 of Art. 130, part 1 of Art. 131, part 2 of Art. 132 of the Constitution fixes the correlation of these spheres from the standpoint of territorial localization of power and the range of issues that are decided by the relevant subjects of public authority.

At the same time, local self-government bodies are limited by the possibility of exercising their power within settlements and other local territories and by a range of issues to be resolved, which are excluded from the scope of activities of state entities in favor of local self-government (Antsiferov, 2019:13). Most of the national projects developed by federal bodies are designed for a long period and are closely related to the subjects of jurisdiction and powers of local self-government bodies. In this regard, inclusion of local self-government bodies into a unified system of public authority is intended to ensure the interaction of state and municipal bodies necessary for

\footnotetext{
${ }^{6}$ Constitution of the Russian Federation. Adopted by popular vote on December 12, 1993 (with changes approved during the all-Russian vote on July 1, 2020). Rossiyskaya Gazeta. 1993 December 25 (No. 237); Russian newspaper. 2020.4 July (No. 144).

${ }^{7}$ Constitution of the Russian Federation. Adopted by popular vote on December 12, 1993 (with changes approved during the all-Russian vote on July 1, 2020). Rossiyskaya Gazeta. 1993 December 25 (No. 237); Russian newspaper. 2020.4 July (No. 144).
} 
implementation of national projects, as well as participation of citizens in managing local affairs, since national projects cannot be fully implemented without effective interaction of all public authorities, on the one hand, and control by state authorities over local self-government bodies, on the other hand.

Thus, the task of improving the quality of life and the time necessary for its implementation requires a vertical of power constructed on the principles of coordination and subordination. Therefore, the logic of the Constitution of the Russian Federation establishes not only restrictions for public authorities in matters subordinate to local self-government bodies, but also enshrines the responsibility of public authorities to ensure effective functioning of local self-government bodies applying the mechanisms subject to jurisdiction of state bodies.

\section{Conclusion}

The updated text of the Constitution of the Russian Federation was the result of the constitutional reform of 2020. All the introduced amendments brought the interaction of state authorities and local self-government bodies to a new level, from now on de jure included in the unified system of public authorities. As elements of the system of democracy, state power and local self-government are the basis of the constitutional order. They have their own set of functions and tasks aimed at ensuring good living standards for the citizens of the Russian Federation.

State authorities and local self-government bodies have public authority, which allows them to be combined into a single system of public power. Nevertheless, the combination of these institutions into a single structure creates the need to develop a clear delineation of the competence of authorities at different levels and detailed legislative consolidation of their interaction and subordination, since in the basic law these distinctions are presented in a generalized form and require detailing in federal legislation. At the same time, the unconditional positive result of the amendments to the Constitution of the Russian Federation were the steps to increase guarantees for the effective implementation of the public authority functions.

The study of the interim results of the novels' introduction into the Constitution in terms of organization of public authorities allows us to emphasize the further strengthening of the vertical of power and constitutional consolidation of local selfgovernment bodies as an integral part of the unified system of public power. At the same time, the significance of the inclusion of local self-government bodies in the unified system of public authority can be fully seen only after completion of the process of novelties' legislative consolidation declared in the main law of the state and their further application in practice.

\section{References / Список литературы}

Antsiferov, N.V. (2019) Some aspects of the category «public authority» in the context of local selfgovernment. In: Chikhladze L.T. (ed.). Problems and prospects for the development of local self-government in the Russian Federation: collection of articles. materials of the All-Russian scientific-practical conference. Moscow, RUDN Publ. Pp. 9-17. (in Russian). 
Анциферов Н.B. Некоторые аспекты категории «публичная власть» в контексте местного самоуправления // Проблемы и перспективы развития местного самоуправления в Российской Федерации: сб. материалов Всероссийской научно-практической конференции / под ред. Л.Т. Чихладзе. М.: РУДН, 2019. С. 9-17.

Avakyan, S.A. (2018) The structure of public power in Russia: problems of formation and development. Vestnik of Siberian Law Institute of the MIA of Russia. 4 (33), 7-13. (in Russian).

Авакьян C.A. Структура публичной власти в России: проблемы формирования и развития // Вестник Сибирского юридического института МВД России. 2018. № 4 (33). C. $7-13$.

Baytin, I.M. (2005) The essence of law (Modern normative legal thinking on the verge of two centuries). Moscow, Law and State Publ. (in Russian).

Байтин И.М. Сущность права (Современное нормативное правопонимание на грани двух веков). М.: Право и государство, 2005. 544 с.

Belyavsky, N.N. (1904) Police law. Lecture notes. Yuryev Without Publ. (in Russian).

Белявский Н.Н. Полицейское право. Конспект лекций. Юрьев: [Б. и.], 1904. 334 с.

Byalkina, T.M. (2006) Competence of local self-government: problems of theory and legal regulation: monograph. Voronezh, Voronezh State University Publ. (in Russian).

Бялкина T.M. Компетенция местного самоуправления: проблемы теории и правового регулирования: монография. Воронеж: Изд-во Воронеж. гос. ун-та, 2006. 406 с.

Chepurnova, N.M. \& Filippova, A.V. (2011) Municipal law of the Russian Federation: educational and practical guide. Moscow, Yevraziyskiy otkrytyy institute Publ. (in Russian)

Чепурнова Н.М., Филиппова А.В. Муниципальное право Российской Федерации: учебнопрактическое пособие. М.: Евразийский открытый институт, 2011. 559 с.

Chertkov, A.N. (2021) The ratio of democracy and public power: conceptual unity and practical interdependence. In: Vinogradov, V.A. \& Larichev, A.A. (ed.). Democracy as a constitutional value: legal regulation and guarantees of implementation. Collective monograph. Moscow, HSE Publishing House Publ. Pp. 48 - 63. https://doi.org/10.17323/978-5-7598-2350-6

Чертков А.Н. Соотношение народовластия и публичной власти: концептуальное единство и практическая взаимообусловленность // Народовластие как конституционная ценность: правовое регулирование и гарантии реализации: коллективная монография / отв. ред. В.А. Виноградов, А.А. Ларичев. М: Изд. Дом Высшей школы экономики, 2021. C. 48-63. https://doi.org/10.17323/978-5-7598-2350-6

Chestnov, I.L. (2019) Actual problems of the theory of state and law. Textbook: in 2 Parts. Part 1. Actual problems of the theory of the state. Saint Petersburg, Saint Peterburg legal institute (branch) of the University of the Prosecutor's Office of the Russian Federation Publ. (in Russian).

Честнов И.Л. Актуальные проблемы теории государства и права: учебное пособие: в 2 ч. Ч. 1. Актуальные проблемы теории государства. СПб.: Санкт-Петербург. юрид. ин-т (филиал) Университета прокуратуры Рос. Федерации, 2019. 63 с.

Chikhladze, L.T., Laricheva, A.A. \& Khazova, Ye.N. (eds.). (2020) Local self-government in a unified system of public authority. Vector and consequences of constitutional reform in the Russian Federation: monograph. Moscow, Yuniti-Dana Publ. (in Russian).

Местное самоуправление в единой системе публичной власти. Вектор и последствия конституционной реформы в Российской Федерации: монография / под общ. ред. Л.Т. Чихладзе, А.А. Ларичева, Е.Н. Хазова. М.: Юнити-Дана, 2020. 343 с.

Chirkin, V.E. (2008) Russian constitution and public power of the people. State and Law. (12), 24-34. (in Russian).

Чиркин B.E. Российская конституция и публичная власть народа // Государство и право. 2008. № 12. С. $24-34$. 
Degtyareva, R.V. \& Poltorak, S.N. (ed.) (2005) Domestic history: study guide. 2nd edition, revised and enlarged. Moscow, Gardariki Publ. (in Russian).

Отечественная история: учебное пособие / под ред. Р.В. Дегтяревой, С.Н. Полторака. 2-е изд., испр. и доп. М.: Гардарики, 2005. 398 с.

Elkina, A.V., Irtegova, A.E. \& Yagovtsev, A.E. (2020) Local Self-Government bodies as Part of the Public power System in the Russian Federation. International law journal. 3 (3), 5-10. (in Russian).

Елькина А.В., Иртегова А.Е., Яговиев А.Е. Органы местного самоуправления - часть системы публичной власти в Российской Федерации // International law journal. 2020. № 3. T. 3. С. 5-10.

Grigoryan, L.A. (1965) Councils - Bodies of Power and People's Self-Government. Moscow, Politizdat Publ. (in Russian).

Григорян Л.А. Советы - органы власти и народного самоуправления. М.: Политиздат, $1965.204 \mathrm{c}$.

Gurvich, G.S. (1924) The principles of autonomy and federalism in the Soviet system. Moscow, Izdatelstvo sotsialisticheskoy akademii Publ. (in Russian).

Гурвич Г.С. Принципы автономизма и федерализма в советской системе. М.: Изд-во социал. академии, $1924.76 \mathrm{c.}$

Kashkarov, A.A. (2015) On the question about the definition of the Content of «Public Authority» in a modern democratic society. Vestnik of Moscow University of the Ministry of Internal Affairs of Russia. (9), 172-175. (in Russian).

Кашкаров А.А. К вопросу об определении содержания «публичная власть» в современном демократическом обществе // Вестник Московского университета МВД России. 2015. № 9. C. 172-175.

Kavelin, K.D. (1904) Collected works: in 4 volumes: Ethnography and jurisprudence. Saint Petersburg, Izdaniye N. Glagoleva; tipografiya M.M. Stasyulevicha Publ. (in Russian).

Кавелин К.Д. Собрание сочинений: в 4 т.: Этнография и правоведение. СПб.: Издание Н. Глаголева; тип. М.М. Стасюлевича, 1904. Т. 4.1348 с.

Khimich, T.M. (2019) Formation and Evolution of Local Governments in Russia Before the XIX century. Agrarian and land law. 10 (178), 37-39. (in Russian).

Химич T.M. Становление и эволюция органов местного самоуправления в России до начала ХІХ в. // Аграрное и земельное право. 2019. № 10 (178). С. 37-39.

Kim, A.I. (1975) State power and people's representation in the USSR Tomsk, Tomsk State University Publishing House. (in Russian).

Ким А.И. Государственная власть и народное представительство в СССР. Томск: Изд-во Томск. ун-та, 1975. $216 \mathrm{c}$.

Klishas, A.A. (ed.) (2019) Theory of State and Law: Textbook. Moscow, Statut Publ. (in Russian). Теория государства и права: учебник / под ред. д.ю.н., проф. А.А. Клишаса. М.: Статут, 2019. $512 \mathrm{c}$.

Komarov, S.A. (2005) General theory of state and law. Saint Petersburg, Piter Publ. (in Russian). Комаров С.А. Общая теория государства и права. СПб.: Изд-во «Питер», 2005. 512 с.

Kovalevsky, M.M. (1899) The origin of modern democracy. Edition 2. Vol. 1, Part 3-4. Moscow, Izdanie K.T. Soldatenkova; Tipo-litografiya V. Rikhtera Publ. (in Russian).

Ковалевский М.М. Происхождение современной демократии. Изд. 2-е. Т. 1, ч. 3 - 4. М.: Издание К.Т. Солдатенкова; Типо-литография В. Рихтера, 1899. 589 с.

Maliavkina, N.V. (2011) Theoretical and legal aspects of public authority in the Russian Federation. Central Russian Journal of Social Sciences. (4), 124-130. (in Russian).

Малявкина Н.B. Теоретико-правовые аспекты органа публичной власти в Российской Федерации // Среднерусский вестник общественных наук. 2011. № 4. С. 124-130.

Maltsev, N.L. (2009) About the Notion of the «Function of the Public Authority». Perm University Herald. Yuridical scinces. 1 (3), 25-33. (in Russian). 
Мальцев Н.Л. К вопросу о понятии «функции публичной власти» // Вестник Пермского университета. Юридические науки. 2009. Вып. 1 (3). С. $25-33$.

Nemirovsky, E.Ya. (1924) Soviet criminal law: a guide. The part is general and special. Odessa, Vtoraya gosudarstvennaya tipografiya imeni tovarischa Lenina Publ. (in Russian).

Немировский Э.Я. Советское уголовное право: пособие. Часть общая и особенная. Одесса: Вторая гос. тип. им. т. Ленина, 1924. 295 с.

Raisky, L.G. (1930) Recent history of the North American United States. Leningrad, Priboy Publ. (in Russian).

Райский Л.Г. Новейшая история Северо-Американских Соединенных Штатов. Л.: Прибой, 1930. 246 с.

Shugrina, Ye.S. (2016) Organization of the Public Power in the Constitutional State. Legal Education and Science. (3), 166-171. (in Russian).

Шугрина E. C. Организация публичной власти в конституционном государстве // Юридическое образование и наука. 2016. № 3. С. 166-171.

Sovetov, I.K. (2020) Public authority in Russia under the 2020 Constitution. Bulletin of Prikamsky Social Institute. 3 (87), 43-52. (in Russian).

Советов И.К. Публичная власть в России по Конституции 2020 года // Вестник Прикамского социального института. 2020. № 3 (87). С. 43-52.

Suslin, E.V. \& Rybin, D.V. (2018) Theory of State and Law: Textbook. Saint Petersburg, Saint Petersburg Law Academy Publ. (in Russian).

Суслин Э.В., Рыбин Д.В. Теория государства и права: Учебное пособие. СПб.: Изд-во Санкт-Петербург. юрид. академии, 2018. 244 с.

Talberg, D.G. (1880) Violent theft of property under Russian law. Historical and dogmatic research. Saint Petersburg, Tipografiya V. S. Balasheva Publ. (in Russian)

Тальберг Д.Г. Насильственное похищение имущества по русскому праву. Историкодогматическое исследование. СПб.: Тип. В.С. Балашева, 1880. 200 с.

Tarasova, E.P. (2010) Correlation of Definitions: Politician authority and State authority. Sociology of power. (5), 164-172. (in Russian).

Тарасова Е.П. Соотношение понятий «политическая власть» и «государственная власть» // Социология власти. 2010. № 5. С. 164-172.

Vasiliev, V.I. (2019) Local Self-Government and the Constitution of the Russian Federation. Journal of Russian Law. (6), 28 -35. https://doi.org/10.12737/jrl.2019.6.3 (in Russian.). Васильев В.И. Местное самоуправление и Конституция Российской Федерации // Журнал российского права. 2019. № 6. С. 28 -35. https://doi.org/10.12737/jrl.2019.6.3

Vlasenko, N.A. (2011) Theory of State and Law: Textbook. 2nd edition. Moscow, Prospekt Publ. Власенко Н.A. Теория государства и права: учебник / Институт законодательства и сравнительного правоведения при Правительстве Российской Федерации. 2-е изд. М.: Проспект, 2011. 413 с.

Yeremyan, V.V. \& Fedorov, M.V. (1998) Local government in Russia (XII - early XX centuries): textbook. Moscow, New Lawyer Publ. (in Russian).

Еремян В.В., Федоров М.В. Местное самоуправление в России (XII - начало XX вв.): учебное пособие. М.: Новый Юрист, 1998. 174 с.

\section{About the authors:}

Chikhladze Levan Teimurazovich - Doctor of Legal Sciences, Full Professor, Head of the Department of Municipal Law, Law Institute, Peoples' Friendship University of Russia (RUDN University); 6 Miklukho-Maklaya str., Moscow, 117198, Russian Federation

ORCID ID: 0000-0002-8807-2572; SPIN-code: 3018-2946

e-mail: chikhladze_1t@rudn.university 
Ganina Olga Yurievna - Candidate of Historical Sciences, Associate Professor of the Department of Constitutional and International Law, Orenburg Institute (branch), Moscow State University named after O.E. Kutafina (Moscow State Law Academy); 50 Komsomolskaya str., Orenburg, 460000, Russian Federation

ORCID ID: 0000-0003-4334-6282; SPIN-code: 4808-4610

e-mail: ogau2007@mail.ru

\section{Об авторах:}

Чихладзе Леван Теймуразович - доктор юридических наук, профессор, заведующий кафедрой муниципального права, Юридический институт, Российский университет дружбы народов (РУДН); 117198, Российская Федерация, г. Москва, ул. Миклухо-Маклая, д. 6

ORCID ID: 0000-0002-8807-2572; SPIN-код: 3018-2946

e-mail: chikhladze_lt@rudn.university

Ганина Ольга Юрьевна — кандидат исторических наук, доцент, доцент кафедры конституционного и международного права, Оренбургский институт (филиал), Московский государственный университет имени О.Е. Кутафина (МГЮА); 460000, Российская Федерация, г. Оренбург, ул. Комсомольская, д. 50

ORCID ID: 0000-0003-4334-6282; SPIN-code: 4808-4610

e-mail: ogau2007@mail.ru 